\title{
Physiological and biochemical measurements before, during and after pregnancy of healthy rats ${ }^{1}$
}

\author{
Silvana Barroso CorvinoI, Gustavo Tadeu Volpato ${ }^{\text {II }}$, Nathália Cristine Dias Macedo ${ }^{\text {III, }}$ Yuri Karen Sinzato ${ }^{\mathrm{IV}}$, Marilza Vieira \\ Cunha Rudgev ${ }^{\mathrm{v}}$ Débora Cristina Damasceno ${ }^{\mathrm{VI}}$
}

DOI: http://dx.doi.org/10.1590/S0102-865020150100000003

${ }^{\mathrm{P} h D}$, Laboratory of Experimental Research on Gynecology and Obstetrics, Postgraduate Program in Gynecology, Obstetrics and Mastology, Botucatu Medical School, Universidade Estadual Paulista (UNESP), Botucatu-SP, Brazil. Conception, design, intellectual and scientific content of the study; acquisition, interpretation and analysis of data; manuscript writing; critical revision.

IIPhD, Full Professor, Institute of Biological and Health Sciences, University Center of Araguaia, Universidade Federal do Mato Grosso (UFMT), Barra do Garças-MT, Brazil. Interpretation and analysis of data, critical revision.

${ }^{\mathrm{II}}$ Fellow Master degree, Laboratory of Experimental Research on Gynecology and Obstetrics, Postgraduate Program in Gynecology, Obstetrics and Mastology, Botucatu Medical School, UNESP, Botucatu-SP, Brazil. Technical procedures.

${ }^{\text {IV }} \mathrm{PhD}$, Laboratory of Experimental Research on Gynecology and Obstetrics, Postgraduate Program in Gynecology, Obstetrics and Mastology, Botucatu Medical School, UNESP, Botucatu-SP, Brazil. Interpretation and analysis of data, critical revision.

${ }^{v} \mathrm{PhD}$, Head and Full Professor, Postgraduate Program in Gynecology, Obstetrics and Mastology, Botucatu Medical School, UNESP, Botucatu-SP, Brazil. Design of the study.

${ }^{\mathrm{V}} \mathrm{PhD}$, Head and Full Professor, Laboratory of Experimental Research on Gynecology and Obstetrics, Postgraduate Program in Gynecology, Obstetrics and Mastology, Botucatu Medical School, UNESP, Botucatu-SP, Brazil. Interpretation and analysis of data, critical revision.

\section{ABSTRACT}

PURPOSE: To analyze the physiological and biochemical measurements before, during and after pregnancy of healthy rats.

METHODS: Wistar adult females rats $(n=8)$ were weighed and blood samples were obtained before, during and after pregnancy for biochemical determinations, chow intake, water consumption and milk production were evaluated. At day 10 postpartum, the rats were killed for weighing of organs and adipose tissues.

RESULTS: The results showed increase in body weight, serum insulin and ingestion of water and chow. At day 17 pregnancy, presented normal values in the OGTT. At days 7, 14 and 20 of pregnancy, there was increase in triglyceride levels. At term pregnancy, there was weight gain due to fetal growth. In the postpartum period presented reduced blood glucose levels. The glycemic means were reduced during and after pregnancy compared to after pregnancy. The triglyceride concentrations were increased before and during pregnancy in relation to after pregnancy. The total cholesterol levels presented no changes.

CONCLUSION: The use of experimental animals is suitable for evaluation of metabolic changes because the profile of answers found in this study was similar to human profile, showing the relevance of translational research to better understand the pathophysiological mechanisms and possible treatment for diseases.

Key words: Pregnancy. Physiology. Rats. 


\section{Introduction}

The studies conducted by animal experimentation are relevant related to its contribution to human health, the knowledge development and the society improvement ${ }^{1}$. During researches related to reference values of healthy animals in several database, our research group found difficulties involving reference values in pregnancy and postpartum-related healthy laboratory rats. To indicate reference values for biochemical parameters it is necessary to develop manual techniques characterized by a low risk of laboratory error, leading to precision and repeatability of measurements ${ }^{2,3}$.

The methods of blood analysis in experimental animals may be applied to evaluate biochemical markers, which are based on various laboratory techniques ${ }^{4}$. Therefore, it is necessary to develop adequate experimental models using laboratory animals. These models are relevant to expand and improve the understanding of the pathophysiological mechanisms ${ }^{5}$ and to contribute for scientific knowledge in various research areas ${ }^{6}$. We hypothesized that the physiological and biochemical parameters are changed in different moments (pre, pregnancy and post pregnancy). Thus, the objective of this study was to analyze physiological and biochemical measurements in healthy Wistar rats and to compare them before, during and after pregnancy of these animals.

\section{Methods}

This study was approved by Ethical Committee for Animal Research of the UNESP, Brazil (protocol number: 938/2012).

Female and male Wistar rats were obtained of CEMIB (Universidade Estadual de Campinas - UNICAMP, Sao Paulo) weighing approximately 200 grams (g), and the animals were housed in a certified animal care. The rats were maintained on Laboratory of Experimental Research on Gynecology and Obstetrics under controlled conditions (temperature $22 \pm 2^{\circ} \mathrm{C}$, humidity $55 \pm 5 \%$ and $12 \mathrm{~h}$ light/dark cycle), and chow (Purina ${ }^{\circledR}$ rodent chow, Brazil) and water were provided ad libitum and cared for in accordance with the principles of the Guide for Care and Use of Experimental Animals. According the statistical design, the same eight $(n=8)$ rats were used throughout the experiment.

\section{Evaluation of physiological and biochemical parameters before pregnancy}

\section{Oral glucose tolerance test (OGTT)}

For OGTT, at mornings of days 90 (adult life) and 120 (adult life and early period of mating), after fasting for six hours, a glucose solution $(200 \mathrm{~g} / \mathrm{L})$ was administered by gavage at a final dose of $2 \mathrm{~g} / \mathrm{kg}$ body weight. Following, the blood samples were obtained by a small cut tip of the tail for blood glucose levels determination using a specific glucometer (OneTouch UltraJohnson \& Johnson ${ }^{\circledR}$ ) in the first timepoint (zero). For obtaining of the blood samples at 30,60, and 120 minutes (min), a massage on the tail was performed toward the same small cut tip. The glycemic values were expressed in $\mathrm{mg} / \mathrm{dL}^{7}$ (Figure 1).

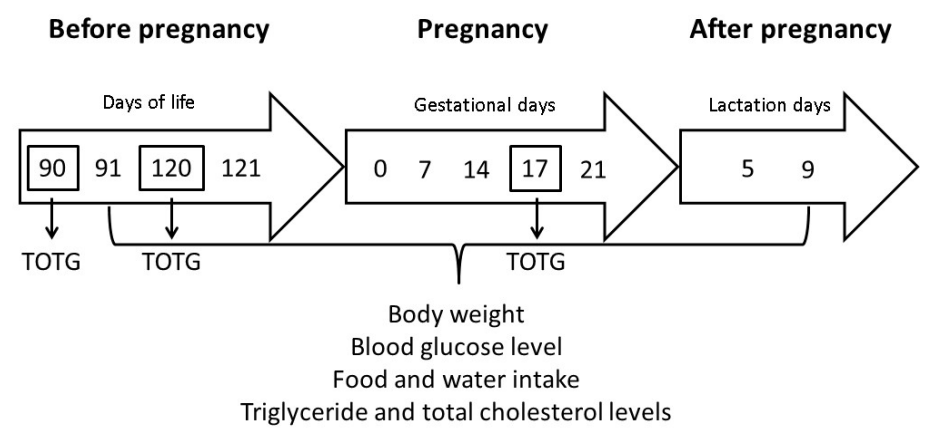

FIGURE 1 - Experimental design.

$\underline{\text { Physiological and biochemical parameters analyzed }}$ before pregnancy (pre pregnancy period)

At mornings of days 91 and 121 of life, maternal body weights, post prandial glycemia, triglyceride and total cholesterol levels were determined. All blood samples were obtained from a small cut tip tail. Blood glucose concentrations were measured by conventional glucometer and these values were expressed in $\mathrm{mg} / \mathrm{dL}$. For evaluation of triglycerides and total cholesterol levels, Accutrend ${ }^{\circledR}$ Plus (Roche Diagnostics GmbH, Mannheim, Germany) was used and the values were also expressed as mg/dL. The $24 \mathrm{~h}$-chow $(\mathrm{g})$ and water $(\mathrm{mL})$ intakes were calculated.

\section{Mating and pregnancy}

At day 120 of life, the same female Wistar rats were mated overnight with male rats. The day when sperms were found in the vaginal smear was designated as gestational day $0^{8}$. The mating period consisted of 15 consecutive days, a period comprising approximately three estral cycles, until a replicate number was obtained. However, during this period, nonmated female rats were considered to be infertile and were discarded from the study ${ }^{9}$.

\section{Evaluation of physiological and biochemical parameters during pregnancy}

During pregnancy, post prandial blood samples were collected at days 0 (early pregnancy), 7 (embryonic period), 14 
(fetal period) and 20 of pregnancy (end of pregnancy - at term pregnancy), with respect to the same parameters following the methodology described in item 2.2. For this, at day 14 of pregnancy, post prandial blood samples were collected to determine insulin concentration (Crystal Chemical - ELISA Kit 90010 - Rat Insulin Elisa kit; Crystal Chemical Company, Harris County, Texas). At day 17 of pregnancy, OGTT was performed in all these rats to evaluate the presence or absence of glucose intolerance following the methodology described in item 2.1.

\section{Evaluation of physiological and biochemical parameters after pregnancy}

The litter size was adjusted at birth eight newborns (four male and four female), which were maintained with their mother during 10 days of lactation. At days 5 (half of lactation period) and 9 (end of experiment), maternal body weights, post prandial glycemia, triglyceride and total cholesterol levels were determined. All blood samples were obtained by venous puncture of the tail. Blood glucose concentrations were measured by conventional glucometer. For evaluation of triglycerides and total cholesterol levels, Accutrend ${ }^{\circledR}$ Plus was also used. In the same days, the pups were removed from their mothers for $4 \mathrm{~h}$ during which mothers ate ad libitum and were weighed at the beginning and end of the $4 \mathrm{~h}$ period for obtaining indirect milk production in the absence of breastfeeding to offspring ${ }^{10}$. The water consumption (mL) and chow intake $(\mathrm{g})$ consumed were measured after 24 hours in analytical balance and beakers, respectively.

At day 10 after delivery, the dams were weighed and anesthetized with sodium pentobarbital $\left(\right.$ Hypnol $^{\circledR}-50 \mathrm{mg} / \mathrm{kg}$ body weight) for laparoscopy procedure. This procedure was carried out by an incision in the medium line beginning in the xiphoid cartilage and ending in the pubis. The intestinal loops were moved cranially for uterus exposure. The hysterectomy was accomplished with the ligament, artery and ovarian vein section and incision of the body uterine above the cervix. Afterward, the uterus and his content were weighed using analytical balance. Rapidly, the stomach was moved to the right to expose the liver, heart, lung pancreas, adipose tissues (peritoritoneal, periovarian, periuterine, pancreatic and sternal) and mammary gland. These organs were dissected and weighed to obtain the maternal relative weight (absolute weight / body weight $x$ 100). Regarding adipose tissues, the calculation of total fat (sum of all adipose tissues) and relative weight (total body fat / body weight x100) were performed.

\section{Statistical analysis}

The number of rats used was eight, which were not sisters because were obtained of different mothers to minimize the maternal influence. The data were presented as mean \pm standard deviation. The comparison were analyzed by $t$ test, Gamma distribution followed by repeated measures, and two-way ANOVA followed Tukey's multiple comparison test. $P<0.05$ was considered as statistical limit of significance.

\section{Results}

\section{Data obtained before pregnancy}

It was verified increase in body weight, serum insulin, water intake and chow consumption of Wistar rats at day 121 of life compared to these same parameters at day 91 of life (Table 1).

TABLE 1 - Body weight and biochemical determinations before pregnancy of healthy Wistar rats.

\begin{tabular}{|c|c|}
\hline Variables & $(\mathrm{n}=8)$ \\
\hline \multicolumn{2}{|c|}{ Body weight (g) } \\
\hline Day 91 & $244.8 \pm \mathbf{1 9} .3$ \\
\hline Day 121 & $268.3 \pm 16.5^{*}$ \\
\hline \multicolumn{2}{|c|}{ Blood glucose level (mg/dL) } \\
\hline Day 91 & $110.5 \pm 5.5$ \\
\hline Day 121 & $104.5 \pm 9.2$ \\
\hline \multicolumn{2}{|c|}{ Chow intake $(\mathrm{g})$} \\
\hline Day 91 & $14.6 \pm 1.0$ \\
\hline Day 121 & $16.6 \pm 1.1 *$ \\
\hline \multicolumn{2}{|c|}{ Water consumption (mL) } \\
\hline Day 91 & $39.6 \pm 2.5$ \\
\hline Day 121 & $57.3 \pm \mathbf{2 . 7} *$ \\
\hline \multicolumn{2}{|c|}{ Triglyceride level(mg/dL) } \\
\hline Day 91 & $130.5 \pm \mathbf{1 4 . 6}$ \\
\hline Day 121 & $114.5 \pm 27.1$ \\
\hline \multicolumn{2}{|c|}{ Total cholesterol level (mg/dL) } \\
\hline Day 91 & $158.7 \pm 1.3$ \\
\hline Day 121 & $162.2 \pm 8.3$ \\
\hline
\end{tabular}

Values are expressed as mean \pm standard deviation (SD)

${ }^{*} p<0.05$ - between days 91 and 121 of life ( $t$ test).

During OGTT, there was increase in blood glucose levels at timepoint $30 \mathrm{~min}$ (after glucose overload) compared to timepoint 0 (test start), and reduced blood glucose levels at timepoint 120 min (test final) compared to timepoint $60 \mathrm{~min}$ at days 91 and 121 of life (Figure 2). 


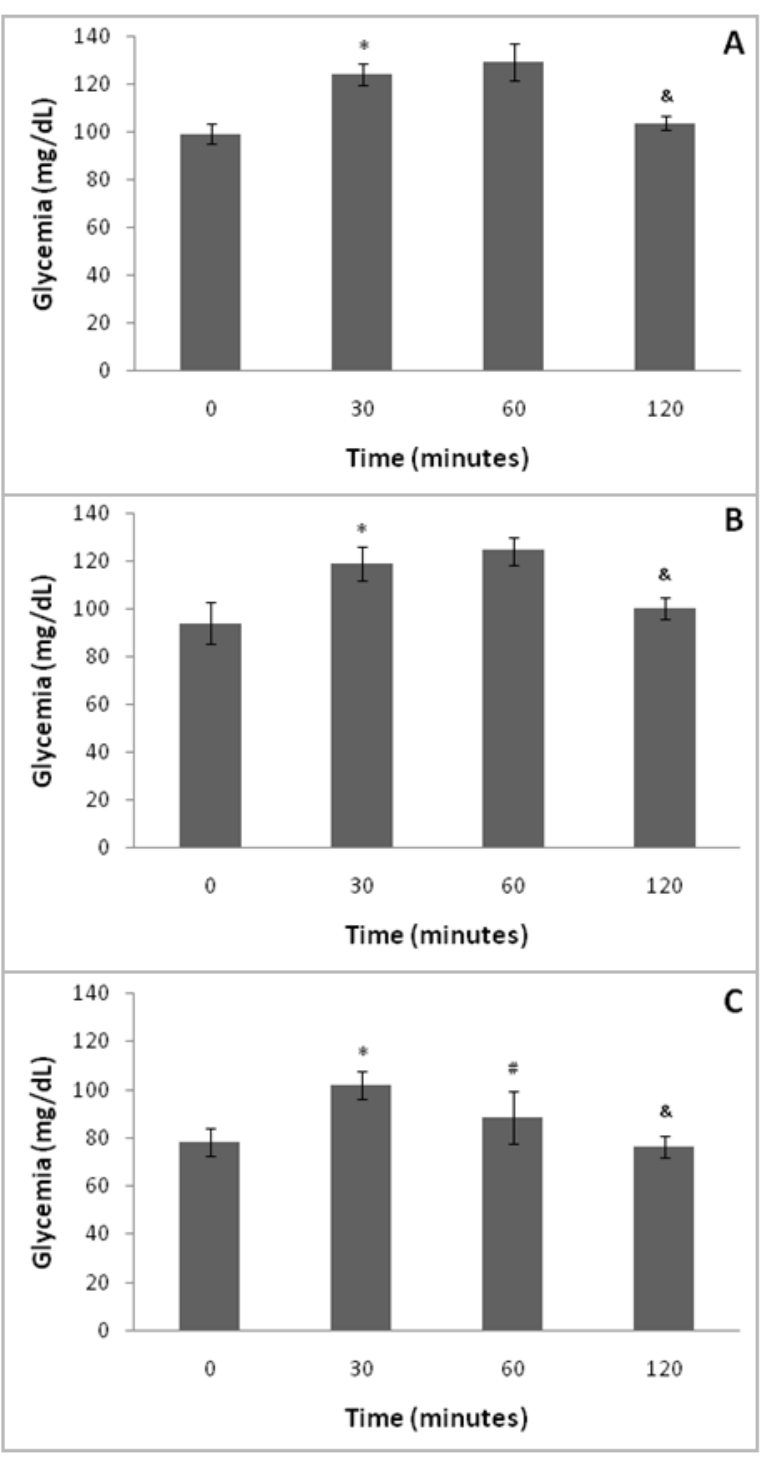

FIGURE 2 - Oral glucose tolerance test (OGTT) at day 90 of life (A), at day 120 of life (B) and at day 17 of pregnancy $(\mathbf{C})$ of healthy Wistar rats $(\mathrm{n}=8)$.

Values are expressed as mean \pm standard deviation (SD). Gamma distribution followed by repeated measures.

$* p<0.05$ - between timepoint zero and timepoint 30 minutes ( $t$ test). ${ }^{\#} \mathrm{p}<0.05$ - between timepoint 30 minutes and timepoint $60 \mathrm{~min}$ ( $\mathrm{t}$ test)

${ }^{\&} \mathrm{p}<0.05$ - between timepoint $60 \mathrm{~min}$ and timepoint $120 \mathrm{~min}(\mathrm{t}$ test).

\section{Data obtained during pregnancy}

The body weight and biochemical parameters were evaluated at days $0,7,14$ and 20 of pregnancy. The rats presented increased body weight at day 20 of pregnancy (end of pregnancy) compared to at day 14 of pregnancy (early fetal growth). The pregnant rats gained 94,0 grams of weight at the end of pregnancy (day 20 of pregnancy) in relation to early pregnancy (day zero). It was verified a progressive increase of triglyceride level throughout pregnancy (from day 0 to day 7 of pregnancy, from day 7 to day 14, and from day 14 to day 20 of pregnancy) (Table 2). At day 17 of pregnancy the dams were submitted to OGTT, and it was observed increased blood glucose level at timepoint $30 \mathrm{~min}$ compared to timepoint 0 , and decreased blood glucose level at timepoint 60 min in relation to timepoint $30 \mathrm{~min}$, and at $120 \mathrm{~min}$ compared to at timepoint $60 \mathrm{~min}$ (Figure 2).

TABLE 2 - Body weight and biochemical determinations during pregnancy of healthy Wistar rats.

\begin{tabular}{cc}
\hline Variables & $(\mathrm{n}=8)$ \\
\hline Body weight $(\mathrm{g})$ & \\
Day zero & $270.8 \pm 18.0$ \\
Day 7 & $288.5 \pm 21.2$ \\
Day 14 & $313.7 \pm 21.3$ \\
Day 20 & $364.8 \pm 27.0^{\&}$ \\
Glycemia (mg/dL) & \\
Day zero & $102.8 \pm 8.0$ \\
Day 7 & $98.0 \pm 4.2$ \\
Day 14 & $88.3 \pm 12.3$ \\
Day 20 & $90.0 \pm 9.3$
\end{tabular}

Serum insulin $(\mathrm{ng} / \mathrm{mL})$

Day 14

$1.2 \pm \mathbf{0 . 7}$

Chow intake (g)

Day zero

$18.0 \pm 2.6$

Day 7

$21.4 \pm 4.0$

Day 14

$23.8 \pm 2.5$

Day 20

$24.3 \pm 3.1$

Water consumption (mL)

Day zero

$54.0 \pm 12.1$

Day 7

$52.5 \pm 20.4$

Day 14

$74.0 \pm 19.7$

Day 20

$62.1 \pm 10.7$

Triglycerides (mg/dL)

Day zero

$92.3 \pm 17.8$

Day 7

$115.1 \pm 10.6^{*}$

Day 14

$169.8 \pm 25.0^{\#}$

Day 20

$255.7 \pm 37.9^{\&}$

Total Cholesterol (mg/dL)

$\begin{array}{cc}\text { Day zero } & 160.7 \pm 2.9 \\ \text { Day } 7 & 116.0 \pm 2.9^{*} \\ \text { Day } 14 & 161.8 \pm 3.8 \\ \text { Day } 20 & 161.7 \pm 4.6\end{array}$

Values are expressed as mean \pm standard deviation (SD). Gamma distribution followed by repeated measures.

$* p<0.05$ - between day zero and day 7 of pregnancy.

${ }^{\#} \mathrm{p}<0.05$ - between day 7 and day 14 of pregnancy.

${ }^{\star} \mathrm{p}<0.05$ - between day 14 and day 20 of pregnancy. 


\section{Data obtained after pregnancy}

During lactation period (days 5 and 9), the body weight, blood glucose level, water intake, chow consumption, triglyceride and total cholesterol levels, and milk production presented no significant statistically difference throughout lactation period. The mean weights of organs (in grams) obtained at day 10 of lactation were: heart $(0.35 \pm 0.04)$, pancreas $(0.24 \pm 0.03)$, lung $(0.50 \pm 0.06)$, liver (3.45 \pm 0.121$)$, and mammary gland $(6.32 \pm 0.89)$. In relation to mean weight (in grams) of adipose tissues: peritoneal (1.34 \pm 0.59$)$, periovarian $(0.28 \pm 0.12)$, periuterine $(0.70 \pm 0.22)$, pancreatic $(0.19 \pm 0.10)$, sternal $(0.07 \pm 0.03)$, total fat $(8.41 \pm 2.52)$, and relative fat $(0.85 \pm 0.29)$ (Table 3$)$.

TABLE 3 - Body weight, biochemical determinations and milk production after pregnancy (day 10 of lactation period) of healthy Wistar rats.

\begin{tabular}{|c|c|}
\hline Variables & $(\mathrm{n}=8)$ \\
\hline \multicolumn{2}{|l|}{ Body weight(g) } \\
\hline Day 5 & $300.3 \pm 25.9$ \\
\hline Day 9 & $314.5 \pm 21.9$ \\
\hline \multicolumn{2}{|c|}{ Glycemia (mg/dL) } \\
\hline Day 5 & $97.6 \pm 11.0$ \\
\hline Day 9 & $87.0 \pm 3.6$ \\
\hline \multicolumn{2}{|c|}{ Chow intake(g) } \\
\hline Day 5 & $34.4 \pm 7.1$ \\
\hline Day 9 & $38.6 \pm 8.7$ \\
\hline \multicolumn{2}{|c|}{ Water consumption (mL) } \\
\hline Day 5 & $124.7 \pm 25.5$ \\
\hline Day 9 & $139.8 \pm 41.9$ \\
\hline \multicolumn{2}{|c|}{ Triglycerides (mg/dL) } \\
\hline Day 5 & $86.1 \pm 7.2$ \\
\hline Day 9 & $94.3 \pm 15.9$ \\
\hline \multicolumn{2}{|c|}{ Total Cholesterol (mg/dL) } \\
\hline Day 5 & $161.8 \pm 7.5$ \\
\hline Day 9 & $160.2 \pm 7.4$ \\
\hline \multicolumn{2}{|c|}{ Milk production $(\mathrm{g})$} \\
\hline Day 5 & $3.3 \pm 1.1$ \\
\hline Day 9 & $3.8 \pm 3.2$ \\
\hline
\end{tabular}

Values are expressed as mean \pm standard deviation (SD)

$\mathrm{p}>0.05$ - no statistically significant difference

\section{Comparison of the biochemical data obtained be- fore, during and after pregnancy}

The glycemic means were reduced during and after pregnancy compared to after pregnancy. The triglyceride concentrations were increased before and during pregnancy in relation to after pregnancy. The total cholesterol levels presented no changes regardless of period (Table 4).

TABLE 4 - Biochemical determinations before, during and after pregnancy of healthy Wistar rats.

\begin{tabular}{cccc}
\hline Variables & Pre-pregnancy & Pregnancy & $\begin{array}{c}\text { Post-preg- } \\
\text { nancy }\end{array}$ \\
\hline $\begin{array}{c}\text { Glycemia } \\
(\mathrm{mg} / \mathrm{dL})\end{array}$ & $110.9 \pm \mathbf{1 3 . 7}$ & $93.1 \pm \mathbf{9 . 7 *}$ & $92.3 \pm \mathbf{9 . 6 *}$ \\
$\begin{array}{c}\text { Triglycerides } \\
(\mathrm{mg} / \mathrm{dL})\end{array}$ & $122.5 \pm \mathbf{2 3 . 4}$ & $180.2 \pm \mathbf{6 4 . * 7}$ & $90.3 \pm \mathbf{1 2 . 5 * \#}$ \\
$\begin{array}{l}\text { Total Cholesterol } \\
(\mathrm{mg} / \mathrm{dL})\end{array}$ & $160.5 \pm \mathbf{6 . 3}$ & $163.2 \pm \mathbf{4 . 2}$ & $161.0 \pm \mathbf{7 . 1}$ \\
$\begin{array}{l}\text { Values are expressed as mean } \pm \text { standard deviation (SD). Two-way ANOVA fol- } \\
\text { lowed Tukey's multiple comparison test } \\
\text { *p }<0.05 \text { - compared to Pre-pregnancy period. } \\
{ }^{\# p}<0.05 \text { - compared to Pregnancy period. }\end{array}$ &
\end{tabular}

\section{Discussion}

The increased consumption of water and chow (days 91 and 121 of life) as there was the body growth contributed to weight gain throughout life. This weight gain is compatible with the findings of Tomanari et al. ${ }^{11}$, who found an increased weight in rats had free access to water and food due to the rapid mass weight gain in the first month of life and became slow in other periods of life.

Regarding the triglyceride concentration, our findings corroborate the findings of Całkosiński et al. ${ }^{12}$, who found that triglyceride levels of laboratory animals did not differ throughout life during the period studied (from day 91 of life to day 10 of lactation). However, another study perfomed by Vega et al. ${ }^{13}$ demonstrated that control rats with 120 days of life presented lower triglyceride levels in relation to those found in our investigation. In the present study, the cholesterol levels showed no difference in the two ages analyzed, however the values are not compatible with the literature ${ }^{12}$, who verified low values, suggesting that the methods used for cholesterol concentration measurement could have interfered in controversial results.

It is already demonstrated that insulin secretion is biphasic. The first phase occurs in the first ten minutes after a stimulus, and it is acute and has a short duration. It consists of the preformed insulin. It is of fundamental importance for the control of postprandial glucose levels. A continuous glycemic stimulus induces the second phase of insulin secretion, which is less intense and more prolonged ${ }^{14,15}$. In our study, it was found before pregnancy that the pancreas was tolerant to glucose stimulus during oral 
glucose tolerance test, confirmed by adequate insulin secretion due to the blood glucose levels maintenance below $140 \mathrm{mg} / \mathrm{dL}$ (minimum reference value for intolerance glucose) and below 200 $\mathrm{mg} / \mathrm{dL}$ (minimum reference value for Diabetes mellitus) ${ }^{16}$.

The weight gain at the end of pregnancy in rats shows fetal growth period starting from day 18 of pregnancy ${ }^{17}$. Then, the increased fetal weight consequently led to maternal weight gain on day 20 pregnancy ${ }^{18-22}$. The progressive increase in triglyceride levels during pregnancy may be related to preparation for lactogenesis and also for the milk production or feeding of offspring. Increments in circulating VLDL-triglycerides are seen in pregnant women during the third trimester of gestation play an important role in the fate of circulating triglycerides, which are diverted from uptake by adipose tissue to uptake by the mammary gland for milk synthesis ${ }^{23}$. Our findings showed no alteration in chow consumption and water intake during pregnancy. However, Bautista et al. ${ }^{24}$ observed increased food intake from day 10 to day 16 of pregnancy, a period that corresponds to the initiation of major fetal organ growth and augmented cell proliferation.

The oral glucose tolerance test (OGTT) applied during pregnancy showed reduced glucose values compared to the other life periods. This finding may be due to test application period (day 17 of pregnancy), which is the peak of development and fetal growth. However, these rats showed adequate response to OGTT, i.e., showed an increase in blood glucose after glucose overload and adequate glycemic return at end of test, confirming the absence of glucose intolerance or Diabetes mellitus. The fact that there have been no change in parameters studied during lactation may be related to the period of analysis, suggesting that after day 14 of lactation there are variations noticeable in the physiological and biochemical parameters.

In relation the physiological and biochemical changes in the different periods analyzed, it was observed that the rats gained body weight during pregnancy related to fetal and extraembryonic membranes development, according to others studies of our laboratory ${ }^{18-22}$. The blood glucose level in pregnancy and lactation periods was reduced, showing nutrient exchange from mother to offspring as energy source. It was verified a reduction of triglyceride level in lactation period. Desoye et al. ${ }^{25}$ described lipid and lipoprotein concentrations decreases in postpartum period, and the rhythm of this reduction increases in lactation period, corroborating with our results.

\section{Conclusion}

The use of experimental animals is suitable for evaluation of metabolic changes because the profile of answers found in this study was similar to human profile, showing the relevance of translational research (bench-to-bedside and bedside-to-bench) to better understand the pathophysiological mechanisms and possible treatment for diseases.

\section{References}

1. National Research Council (US) Committee on the National Needs for Research in Veterinary Science. Critical needs for research in veterinary science. Washington (DC): National Academies Press (US); 2005. The National Academies Collection: Reports funded by National Institutes of Health. PMID: 20669456.

2. Henny J, Hyltoft Petersen P. Reference values: from philosophy to a tool for laboratory medicine. Clin Chem Lab Med. 2004;42(7):68691. PMID: 15327000.

3. Queralto JM. Intraindividual reference values. Clin Chem Lab Med. 2004;42(7):765-77. PMID: 15327012.

4. Koller DY. Sampling methods: urine/ blood analysis. Am J Respir Crit Care Med. 2000 Aug;162(2 Pt 2):S31-3. PMID: 10934129.

5. López-Soldado I, Herrera E. Different diabetogenic response to moderate doses of streptozotocin in pregnant rats, and its longterm consequences in the offspring. Exp Diabesity Res. 2003 AprJun;4(2):107-18. PMID: 14630572.

6. Kaynar O, Hayirli A, Yildiz A, Okumu Z, Kisa F, Banu Buyukunal Bal E, Polat H, Erdem Fuat. Reference values for some physiological and biochemical parameters in rats at puberty. J Anim Vet Adv. 2006;5:1121-28. doi: javaa.2006.1121.1128.

7. Santos TM, Sinzato YK, Gallego FQ, Iessi IL, Volpato GT, Dallaqua B, Damasceno DC. Extracellular HSP70 levels in diabetic environment in rats. Cell Stress Chaperones. 2015 Jul;20(4):595603. PMID: 25813004.

8. Sinzato YK, Volpato GT, Iessi IL, Bueno A, Calderon Ide M, Rudge MV, Damasceno DC. Neonatally induced mild diabetes in rats and its effect on maternal, placental, and fetal parameters. Exp Diabetes Res. 2012;2012:108163. PMID: 22778712.

9. Rocha R, Peraçoli JC, Volpato GT, Damasceno DC, Campos KE. Effect of exercise on the maternal outcome in pregnancy of spontaneously hypertensive rats. Acta Cir Bras. 2014 Sep;29(9):5539. PMID: 25252201

10. Bautista CJ, Boeck L, Larrea F, Nathanielsz PW, Zambrano E. Effects of a maternal low protein isocaloric diet on milk leptin and progeny serum leptin concentration and appetitive behavior in the first 21 days of neonatal life in the rat. Pediatr Res. 2008 Apr;63(4):358-63. doi: 10.1203/01

11. Tomanari GY, Pine AS, Silva MTA. Ratos Wistar sob regimes rotineiros de restrição hídrica e alimentar. Rev Bras Ter Comport Cogn. 2003;5:57-71.

12. Całkosiński I, Dobrzyński M, Kobierska-Brzoza J, Majda J, Szymonowicz M, Całkosińska M, Dzierzba K, BronowickaSzydełko A, Sołtan E, Seweryn E, Zasadowski A, Gamian A. The influence of strain, sex and age on selected biochemical parameters in blood serum of Bufalo and Wistar rats. Pol J Vet Sci. 2010;13(2):293-9. PMID: 20731184

13. Vega CC, Reyes-Castro LA, Bautista CJ, Larrea F, Nathanielsz PW, Zambrano E. Exercise in obese female rats has beneficial effects on maternal and male and female offspring metabolism. Int J Obes (Lond). 2015 Apr;39(4):712-9. PMID: 23949616. 
14. Cheng K, Andrikopoulos S, Gunton JE. First phase insulin secretion and type 2 diabetes. Curr Mol Med. 2013 Jan;13(1):126-39. PMID 22834840 .

15. Fehse F, Trautmann M, Holst JJ, Halseth AE, Nanayakkara N, Nielsen LL, Fineman MS, Kim DD, Nauck MA. Exenatide augments first- and second-phase insulin secretion in response to intravenous glucose in subjects with type 2 diabetes. J Clin Endocrinol Metab. 2005 Nov;90(11):5991-7. PMID: 16144950.

16. Damasceno DC, Sinzato YK, Bueno A, Netto AO, Dallaqua B, Gallego FQ, Iessi IL, Corvino SB, Serrano RG, Marini G, Piculo F, Calderon IM, Rudge MV. Mild diabetes models and their maternalfetal repercussions. J Diabetes Res. 2013;2013:473575. PMID: 23878822.

17. Barr M Jr. Prenatal growth of Wistar rats: circadian periodicity of fetal growth late in gestation. Teratology. 1973 Jun;7(3):283-7. PMID: 4807130.

18. Damasceno DC, Silva HP, Vaz GF, Vasques-Silva FA, Calderon IM, Rudge MV, Campos KE, Volpato GT. Diabetic rats exercised prior to and during pregnancy: maternal reproductive outcome, biochemical profile, and frequency of fetal anomalies. Reprod Sci. 2013 Jul;20(7):730-8. PMID: 23171681.

19. Damasceno DC, Kiss AC, Sinzato YK, de Campos KE, Rudge MV, Calderon IM, Volpato GT. Maternal-fetal outcome, lipid profile and oxidative stress of diabetic rats neonatally exposed to streptozotocin. Exp Clin Endocrinol Diabetes. 2011 Jul;119(7):408-13. PMID: 21667442.

20. Damasceno DC, Sinzato YK, Lima PH, de Souza MS, Campos KE, Dallaqua B, Calderon IM, Rudge MV, Volpato GT. Effects of exposure to cigarette smoke prior to pregnancy in diabetic rats. Diabetol Metab Syndr. 2011 Aug;3:20. PMID: 21851636.

21. Volpato GT, Damasceno DC, Sinzato YK, Ribeiro VM, Rudge MV, Calderon IM. Oxidative stress status and placental implications in diabetic rats undergoing swimming exercise after embryonic implantation. Reprod Sci. 2015 May;22(5):602-8. PMID: 25361551.

22. Saito FH, Damasceno DC, Dallaqua B, Linhares IM, Rudge MV, De Mattos Paranhos Calderon I, Witkin SS. Heat shock protein production and immunity and altered fetal development in diabetic pregnant rats. Cell Stress Chaperones. 2013 Jan;18(1):25-33. PMID: 22821472

23. Herrera E, Lasunción MA, Gomez-Coronado D, Aranda P, LópezLuna P, Maier I. Role of lipoprotein lipase activity on lipoprotein metabolism and the fate of circulating triglycerides in pregnancy. Am J Obstet Gynecol. 1988 Jun;158(6 Pt 2):1575-83. PMID: 3287929.
24. Bautista CJ, Rodríguez-González GL, Torres N, HernándezPando R, Ramírez V, Rodríguez-Cruz M, Nathanielsz PW, Zambrano E. Protein restriction in the rat negatively impacts long-chain polyunsaturated fatty acid composition and mammary gland development at the end of gestation. Arch Med Res. 2013 Aug;44(6):429-36. PMID: 24051037.

25. Desoye G, Schweditsch MO, Pfeiffer KP, Zechner R, Kostner GM. Correlation of hormones with lipid and lipoprotein levels during normal pregnancy and postpartum. J Clin Endocrinol Metab. 1987 Apr;64(4):704-12. PMID: 3546352.

\section{Acknowledgement}

To Talisia C. Moreto for her excellent animal care.

\section{Correspondence:}

Profa. Dra. Débora Cristina Damasceno

Departamento de Ginecologia e Obstetrícia

Faculdade de Medicina de Botucatu - UNESP

Distrito de Rubião Júnior, $\mathrm{s} / \mathrm{n}$

18618-970 Botucatu - SP Brasil

Tel.: (55 14)3880-1631

damascenofmb@gmail.com

Received: Jun 12, 2015

Review: Aug 14, 2015

Accepted: Sep 14, 2015

Conflict of interest: none

Financial source: CAPES

${ }^{1}$ Research performed at Laboratory of Experimental Research on Gynecology and Obstetrics, Botucatu Medical School, Universidade Estadual Paulista (UNESP), Botucatu-SP, Brazil. 